\title{
Dietary exposure estimates of twenty-one trace elements from a Total Diet Study carried out in Pavia, Northern Italy
}

\author{
Giovanna Turconi ${ }^{1}$, Claudio Minoia ${ }^{2}$, Anna Ronchi ${ }^{2}$ and Carla Roggi ${ }^{1}$ \\ ${ }^{1}$ Department of Applied Health Sciences, Section of Human Nutrition and Dietetics, Faculty of Medicine, University of Pavia, \\ Via Bassi, 21, I-27100, Pavia, Italy \\ ${ }^{2}$ Laboratory for Environmental and Toxicological Testing, Salvatore Maugeri Foundation, Pavia, Via S. Maugeri 6, I-27100, \\ Pavia, Italy
}

(Received 29 February 2008 - Revised 16 July 2008 - Accepted 18 July 2008 - First published online 14 November 2008)

The significant role of trace elements in human health is well documented. Trace elements are those compounds that need to be present in the human diet to maintain normal physiological functions. However, some microelements may become harmful at high levels of exposure, or, on the other hand, may give rise to malnutrition, when their exposure is too low. The aim of the present study was to provide a reliable estimate of the dietary exposure of twenty-one trace elements in a Northern Italian area. For this purpose, trace element analyses were undertaken on total diet samples collected from a university cafeteria in Pavia, Northern Italy. The average daily exposure for the adult people was calculated on the basis of food consumption frequency, portion size and trace element levels in foodstuffs. The mean exposure values satisfy the Italian RDA for all the essential trace elements, except for Fe exposure in females, and are well below the Provisional Tolerable Daily Intake for all the toxic compounds, showing that the probability of dietary exposure to health risks is overall small. As far as Fe exposure is concerned, a potential risk of anaemia in the female adult population should be considered, then studies aimed at evaluating the Fe nutritional status of adult Italian women should be addressed. In conclusion, while not excluding the possibility that the daily exposure determined in the present study may not be representative of the population as a whole, this study provides a good estimate of the Italian adult consumer exposure to twenty-one trace elements.

Trace elements: Total Diet Study: Market basket: Northern Italy

The very important and significant role of trace elements in human health is well documented ${ }^{(1)}$. Trace elements are those compounds that need to be present in the human diet in order to maintain normal physiological functions. However, microelements may become harmful at high levels of exposure (e.g. Se, $\mathrm{Cr}, \mathrm{Cu}, \mathrm{Zn})^{(1)}$, or, on the other hand, may give rise to malnutrition, when their exposure is too low. While some elements (e.g. $\mathrm{Cr}, \mathrm{Co}, \mathrm{Cu}, \mathrm{Fe}, \mathrm{Mo}, \mathrm{Mn}, \mathrm{Zn}$ etc.) are essential to health, other elements are likely to be essential (e.g. Ni, B, Va), although their positive role in human nutrition remains to be confirmed. In addition, other elements have no proven essential functions in man and are likely to have adverse physiological effects (e.g. Al, As, Li, Sn) ${ }^{(1)}$.

Furthermore, some elements (e.g. $\mathrm{Pb}, \mathrm{As}, \mathrm{Hg}, \mathrm{Cd}$ ) are well known to be toxic if their exposure through diet and/or inhalation is excessive. For example, exposure to $\mathrm{Pb}$ can be harmful to neuropsychological development, inorganic As has been associated with human cancer and other adverse health effects, organic $\mathrm{Hg}$ compounds are neurotoxins and $\mathrm{Cd}$ may affect renal function ${ }^{(1)}$. Other elements can cause short-term health effects from one incidence of high-level exposure. For example, high concentrations of $\mathrm{Sn}$ in foods can cause stomach upsets.
Finally, a metal can be a nutrient or be a toxic compound depending on its chemical form (e.g. $\mathrm{Cr}^{3+}$ and $\mathrm{Cr}^{6+}$ ).

Indeed imbalance, as well as deficiency or excess in trace element dietary exposure, can have deleterious influences on human health ${ }^{(1,2)}$.

It is well known that the amount of trace elements ingested by man depends on dietary habits as well as on their quantities in foodstuffs that are related to soil characteristics which can affect the bioavailability of elements.

Therefore, estimation of dietary exposure to trace elements in population groups is of great relevance for assessing the adequacy of the diet with respect to essential elements and for evaluating a possible risk for high levels of exposure to those that are toxic.

The Total Diet Study (TDS), consisting of analysing a representative 'market basket' of foods usually prepared for normal consumption, is the best method widely used in several European and extra European countries, aimed at estimating dietary exposure of nutrient and toxic compounds and it represents the most cost-effective and reliable method ${ }^{(3-8)}$. It has the advantage of yielding more refined exposure data, in that foods are analysed 'as consumed' by the eater.

Abbreviations: ICP-MS, inductively coupled plasma MS; ICP-OES, inductively coupled plasma emission spectrometry; NIST, National Institute of Standards \& Technology; PTDI, Provisional Tolerable Daily Intake; SRM, Standard Reference Materials; TDS, Total Diet Study.

* Corresponding author: Dr Giovanna Turconi, fax +39382 987570, email gturconi@unipv.it 
The 'market basket' method is indeed considered an important tool for monitoring nutrient and toxic compound dietary exposure and then assessing compliance with nutritional requirements and with provisional acceptable exposure for toxic elements.

To carry out TDS, samples of food are usually collected in representative centres and weighed out in the proportions in which they are consumed in the total diet. This approach is particularly important because it determines levels of the analytes in foods as they would be consumed, so that they resemble as much as possible the usual pattern of the total diet. Moreover, it is suitable for estimating the dietary exposure of compounds which may be changed as a result of washing, peeling and cooking.

The aim of the present study was to provide a reliable estimate of the dietary exposure to twenty-one trace elements in a Northern Italian area. For this purpose, trace element analyses were undertaken on total diet samples collected from a university cafeteria in Pavia, Northern Italy. The average daily exposure for adults was calculated on the basis of food consumption frequency, portion size and trace element levels in foodstuffs. The estimated ingestion of essential trace elements was then compared with the average requirement values of the Italian $\mathrm{RDA}^{(9)}$, while exposure to toxic elements was compared with the Provisional Tolerable Daily Intake (PTDI), as established by the $\mathrm{FAO} / \mathrm{WHO}^{(1)}$. Comparisons were also made with results of previous world-wide studies. In addition, the contribution of each food group to the mean trace element daily exposure was evaluated.

\section{Materials and methods \\ Food choice and dietary consumption data}

In the present study, the choice of the foods and their consumption data utilized for the formulation of the 'market basket' of this Italian TDS were drawn from the Italian Household National Survey carried out in $1994-6$ by the Italian National Institute for Food and Nutrition Research ${ }^{(10)}$.

This survey is the most representative Italian food consumption study since it covered 1978 subjects randomly selected to be representative of the four main geographical areas in Italy (Northwest, Northeast, Centre, South).

Foods selected representing the same food category were aggregated into six main different food groups using the same aggregation used in the Italian Household National Survey ${ }^{(10)}$ : bread, cereals and potatoes; meat and meat products, fish and fish products, eggs (protein-rich foods); milk and dairy products; fruit and vegetables; sweet foods; beverages.

The cereals food group was composed of four items (bread and pizza, pasta, rice, potatoes); the protein-rich foods of six items (beef, pork, poultry, ham and salami, fish and sea foods, eggs); the milk and dairy products group of three items (milk, yogurt, cheese); the fruit and vegetables group of four items (vegetables, legumes, citrus fruit, fresh fruit); the sweet food group of two items (dessert, ice cream) and the beverage group of four items (mineral water, soft drinks, wine, beer).

\section{Food sampling}

The 'market basket' method was slightly modified. Because our laboratory does not provide a kitchen in which to prepare and cook all the food items purchased in local markets following the Italian traditional recipes as the TDS approach suggests, we collected most samples of foods in a cafeteria. Therefore, raw, cooked and ready-to-eat foods were collected over 2 consecutive weeks in July 2004, from a university cafeteria located in Pavia, Northern Italy. This large cafeteria distributes about 2000 meals/d. When necessary, some foods (pasta, rice, boiled meat, fish, eggs and vegetables) were prepared using local drinking tap water. A sample of each food that was prepared daily was collected. Since the food collection was performed only in July, our dietary estimations did not take into account seasonal variation.

Some traditional breakfast foods, such as biscuits, sweets, cereals and milk, which were not served at the cafeteria, were purchased at three local supermarkets as well as a few foods that were included in the Italian Household National Survey $^{(10)}$, but not served at the cafeteria.

All the foodstuffs (226 from the cafeteria and twenty-two from the supermarkets) are listed in Table 1.

Each sample was weighted, given a name and numerical code, and the list was kept on record. Collected items were immediately transferred to the laboratory where the pre-analytical treatment was performed.

\section{Standards and reagents}

Multielemental standard solutions were obtained from $10 \mathrm{mg} / \mathrm{l}$ and inductively coupled plasma MS (ICP-MS) calibration standard numbers 3, 4, MS3, MS1 (CPI International, Amsterdam, The Netherlands), by dilution with water containing the same amount of acids as the samples.

Distilled water was produced using a Milli- $\mathrm{Q}^{\mathrm{TM}}$ deionizing system (Millipore, Bedford, MA, USA).

Suprapur reagents were used: $\mathrm{HNO}_{3}(65 \% \mathrm{~m} / \mathrm{v}), \mathrm{HCl}$ $(37 \% \mathrm{~m} / \mathrm{v})$ and HF (40\% m/v) (Merck, Darmstadt, Germany).

\section{Certified reference materials}

National Institute of Standards \& Technology (NIST) Standard Reference Materials (SRM) 1573 Tomato Leaves, NIST SRM 1547 Peach Leaves, NIST SRM 1567 Wheat Flour and NIST SRM 1575 Pine Needles were used to evaluate the accuracy of the analytical procedures.

\section{Sample preparation}

Food samples, except for dairy products and beverages, were slightly thawed and cut into pieces. They were then pooled and homogenized with double-distilled and deionized water until completely pureed, by a STERILMIXER blender (PBI International, Milan, Italy). The samples were stored in polypropylene containers and frozen at $-18^{\circ} \mathrm{C}$ until analysis

A microwave CEM model MARS-Xpress (CEM Corp., Matthews, NC, USA) was used to digest all the samples. Digestion vessels were cleaned with $10 \mathrm{ml} \mathrm{HNO}_{3}$ using the microwave cleaning programme and were rinsed with deionized water supplied by a Milli- $\mathrm{Q}^{\mathrm{TM}}$ Laboratory Water System (Millipore). Homogenized samples ( $800 \mathrm{mg}$ ) were added to the digestion vessels with $4 \mathrm{ml} \mathrm{HNO}_{3}, 4 \mathrm{ml} \mathrm{HCl}$ and $200 \mu \mathrm{HF}$. After complete digestion and cooling, the 
Table 1. Food products collected from the cafeteria and bought at the supermarkets

\begin{tabular}{lcr}
\hline No. of samples & No. of samples \\
collected from & bought at the \\
the cafeteria & supermarkets
\end{tabular}

\section{Cereals and tubers}

Bread

Pizza margherita

Pizza (wurstel, ham, onions)

Crackers, breadsticks

Cornflakes

Polenta (thick corn mush)

Pasta with eggplants

and peppers

Pasta with tomato and

ricotta cheese

Pasta with tomato

Pasta amatriciana (tomato and smoked bacon)

Pasta with cream, peas, carrots, potatoes

Pasta with zucchini, eggplants and peppers

Pasta with tuna and tomato

Pasta with gravy

Pasta with tomato and rocket

Pasta with cream and gorgonzola

Pasta with seafood

Pasta with cauliflower

Risotto with spinach

Risotto with pork meat

Risotto with carrots, peas

and potatoes

Risotto with mushrooms

Risotto with peas

Risotto with artichokes

Fried rice balls

Potato dumplings with gravy

Potato dumplings with cream and gorgonzola

Boiled potatoes

Fried potatoes

10

1
1
1

2

1

1

2

1

1

1

1

10

Meat and meat products, fish and fish products, eggs, legumes

Beef steak

Beef shank

Beef stew with peas and potatoes

Meatballs (pork, poultry, eggs)

Pepper stuffed with minced meat

Pork cutlet

Pork cutlet with mushrooms

Roasted turkey

Grilled turkey breast

Roasted chicken (wing, breast)

Breaded chicken breast

Breaded hamburger

Hamburger (pork and turkey)

Tripe

Parma ham

Ham steak

Dried beef

Speck ham

Breaded cod fillet

Fried cod sticks

Boiled shrimps

Flounder

Tuna fish in olive oil

Hard-boiled eggs

Omelette with spinach and

ricotta cheese

Boiled green beans

Boiled peas
Table 1. Continued

\begin{tabular}{|c|c|c|}
\hline Sample & $\begin{array}{l}\text { No. of samples } \\
\text { collected from } \\
\text { the cafeteria }\end{array}$ & $\begin{array}{c}\text { No. of samples } \\
\text { bought at the } \\
\text { supermarkets }\end{array}$ \\
\hline $\begin{array}{l}\text { Stewed peas with tomato } \\
\text { sauce }\end{array}$ & 1 & \\
\hline $\begin{array}{l}\text { Boiled beans (French, } \\
\text { haricot, white) }\end{array}$ & & 3 \\
\hline Green olives & & 1 \\
\hline \multicolumn{3}{|l|}{ Milk and dairy products } \\
\hline Whole milk & & 1 \\
\hline Cream & & 1 \\
\hline $\begin{array}{l}\text { Cheese (fontina, smoked provola, } \\
\text { asiago, taleggio, primo sale) }\end{array}$ & 10 & \\
\hline $\begin{array}{l}\text { Cheese (mozzarella, } \\
\text { Philadelphia, caprino) }\end{array}$ & 10 & \\
\hline Yogurt (apricot) & 1 & \\
\hline Yogurt (banana) & 1 & \\
\hline Yogurt (strawberry) & 1 & \\
\hline Yogurt (raspberry, blackcurrant & 1 & \\
\hline
\end{tabular}

Fruit and vegetables

Boiled carrots

Green salad

Boiled cauliflower

Boiled beetroots

Boiled fennel

Boiled spinach

Boiled Brussels sprouts

Tomato salad

Mixed salad

Mixed big salad (tuna fish,

potatoes, peas, carrots,

olives, tomatoes, green

beans, corn, green salad)

Russian salad (mayonnaise, peas, carrots, potatoes)

Fruit (kiwi, peach, apple, banana)

Citrus fruit (mandarin,

orange, grapefruits)

Nuts, peanuts

Dried apricots

Cakes and desserts

Creamy tiramisù

Chocolate pudding

Crème-caramel pudding

Vanilla pudding

Lemon ice-cream

Vanilla and chocolate ice-cream

3

3

Beverages

Bottled mineral water

Bottled mineral water (sparkling)

Red wine

White wine

Beer

Cola-flavoured carbonated

beverage

Orange-flavoured carbonated

beverage

Lime-flavoured carbonated

beverage

Fats and oils

Olive oil

Seed oil

Butter

Margarine

Total 
samples were filtered and transferred to $50 \mathrm{ml}$ graduated polypropylene tubes and diluted to volume with deionized water.

SRM were handled according to NIST's specifications and were treated as previously described for food samples.

Liquid samples (beverages; $10 \mathrm{ml}$ ) were treated with $4 \mathrm{ml}$ $\mathrm{HNO}_{3}$ and $4 \mathrm{ml} \mathrm{HCl}$, heated at $90^{\circ} \mathrm{C}$ for about $1 \mathrm{~h}$ and, after cooling, diluted to $50 \mathrm{ml}$ with deionized water.

Inductively coupled plasma emission spectrometry (ICPOES) and ICP-MS were used to determine the following twenty-one trace elements: $\mathrm{Al}, \mathrm{B}, \mathrm{Ba}, \mathrm{Be}, \mathrm{Cd}, \mathrm{Ce}, \mathrm{Co}, \mathrm{Cs}$, $\mathrm{Cu}, \mathrm{Fe}, \mathrm{Ge}, \mathrm{Li}, \mathrm{Mo}, \mathrm{Mn}, \mathrm{Ni}, \mathrm{Pb}, \mathrm{Rb}, \mathrm{Sn}, \mathrm{Sr}, \mathrm{V}, \mathrm{Zn}$.

\section{Apparatus and analytical conditions}

Measurements of trace elements were carried out using an inductively coupled plasma mass spectrometer (ELAN 6100 DRCII ICP-MS; Perkin-Elmer SCIEX Instruments, Concord, Ontario, Canada) equipped with a cyclonic spray chamber with a concentric nebulizer, a dynamic reaction cell, a quadrupole mass filter and AS 90plus auto-sampler (Perkin-Elmer). The dynamic reaction cell can be pressurized with reactive gases $\left(\mathrm{CH}_{4}, \mathrm{NH}_{3}\right)$ and is vented and pressurized under computer control. The dynamic reaction cell provides online chemical modification of the ion beam to eliminate interferences. The specificity of interference rejection is obtained through the selection of the reaction gas and the operating conditions. In the vented 'standard mode' no reaction gas is present in the cell.

$\mathrm{B}, \mathrm{Be}, \mathrm{Li}, \mathrm{Ce}, \mathrm{Cs}, \mathrm{Ge}, \mathrm{Mo}$ and $\mathrm{Pb}$ were determined in standard mode while $\mathrm{Al}, \mathrm{Cd}, \mathrm{Ba}, \mathrm{Cu}, \mathrm{Co}, \mathrm{Ni}, \mathrm{Mn}, \mathrm{Rb}, \mathrm{Sn}, \mathrm{V}$ and $\mathrm{Zn}$ were determined in enhanced mode $\left(\mathrm{CH}_{4}, \mathrm{NH}_{3}\right)$.

The ICP-OES analyses were performed on a Perkin-Elmer Optima 4300DV, equipped with a standard torch, a Scotttype spray chamber in Ryton, a Gem-Tip cross-flow nebulizer and an AS-90plus auto-sampler; the detector is a custom, two-dimensional CCD array; the plasma source is a dualview (can be viewed either axially or radially) RF generator. The elements determined by ICP-OES were Al, Mn, Fe and Sr. All the measurements were carried out in axial mode.

\section{Estimation of trace element dietary exposure}

The mean, minimum and maximum trace element daily exposures $(\mathrm{mg} / \mathrm{d}, \mu \mathrm{g} / \mathrm{d}$ or $\mathrm{ng} / \mathrm{d}$ ) were estimated by multiplying the mean, minimum and maximum concentrations $(\mu \mathrm{g} / \mathrm{g}$ or $\mathrm{ng} / \mathrm{g}$ ) in any one food item by the average amount of that food consumed by the North Western Italian adult population ${ }^{(10)}$ expressed as $\mathrm{g}$ food/d or $\mathrm{ml}$ beverage/d. Total exposure of each trace element was then obtained by summing the exposure from all food items, after which they were compared with the average requirement values of the Italian $\mathrm{RDA}^{(9)}$ for essential trace elements, while toxic element exposures were compared with PTDI, as established by the FAO/WHO ${ }^{(1)}$.

In addition, the contribution of each food group to the total daily exposure of each element was evaluated. Food items were aggregated according to the same aggregation in food groups used in the Italian Household National Survey ${ }^{(10)}$ as above earlier. The exposure estimates were based on the average food amounts consumed by the entire population (consumer and non-consumer alike).

\section{Results}

The validation of the analytical methods was carried out using the certified reference materials mentioned earlier.

Accuracy was ascertained by adding to each series of samples one of the certified reference materials; precision was monitored by replicating the entire analytical procedure five times in all cases.

Recovery is acceptable: percentages range from 80 to $120 \%$ depending on the element. Only for elements whose measured concentrations are close to detection limit (V in NIST 1547), or for B in NIST 1547 the recovery is 140 and $70 \%$, respectively.

Precision is also satisfactory: relative standard deviation values are always less than $20 \%$ with the exception of $\mathrm{Cu}$ in NIST 1567 (35\%). Higher relative standard deviation values are found only in the case of elements whose concentrations are less than $0 \cdot 1 \mu \mathrm{g} / \mathrm{g}$.

The results for NIST SRM 1547 Peach Leaves, NIST SRM 1573 Tomato Leaves, NIST SRM 1575 Pine Needles and NIST SRM 1567 Wheat Flour are summarized in Table 2.

The detection limits are $0.05 \mu \mathrm{g} / \mathrm{l}$ for the elements of liquid samples analysed by ICP-MS and $5 \mu \mathrm{g} / \mathrm{l}$ for those determined by ICP-OES. As for the solubilized samples, the detection limits are $0 \cdot 001 \mu \mathrm{g} / \mathrm{g}$ for ICP-MS and $0 \cdot 1 \mu \mathrm{g} / \mathrm{g}$ for ICP-OES.

Table 3 shows the mean, minimum and maximum daily exposure to twenty-one trace elements in the TDS in a Northern Italian town, Pavia, compared with the Italian $\mathrm{RDA}^{(9)}$ for the essential trace elements and with PTDI for the toxic compounds, where these values are provided by $\mathrm{FAO} / \mathrm{WHO}^{(1)}$. The percentage contribution of each estimate compared with the Italian RDA or PTDI is also reported. In addition, results from the literature of various TDS are reported in the same table, so that our data can be easily compared with those of other studies.

Table 4 shows the percentage contribution of each food group to the total daily exposure of twenty-one trace elements. Cereals and tubers is the food category that, in general, mostly contributes to the whole trace element total daily exposure, except for $\mathrm{Ce}$; indeed it provides $97 \%$ of the total Sn daily exposure. Protein-rich foods are a good supply of $\mathrm{Cs}, \mathrm{Cu}, \mathrm{Fe}$, $\mathrm{Rb}$ and $\mathrm{Zn}$; milk and dairy products are the foods that mostly contribute $\mathrm{Al}, \mathrm{Ba}, \mathrm{Ce}, \mathrm{Ni}$ and $\mathrm{Zn}$; fruit and vegetables are good suppliers of all the elements, except for Ce and Sn; finally, the contributions of sweet foods and beverages are negligible.

The Al exposure is $3.58 \mathrm{mg} / \mathrm{d}$ (range $0.28-5.15 \mathrm{mg} / \mathrm{d}$ ), which is well below the Provisional Tolerable Weekly Intake $(7 \mathrm{mg} / \mathrm{kg}$ body weight per week for an adult man of $65 \mathrm{~kg}$ body weight) ${ }^{(1)}$ and it falls in the range of the values reported in the literature $(1.9-12 \mathrm{mg} / \mathrm{d})^{(6,7,11-17)}$.

The B exposure is $1.65 \mathrm{mg} / \mathrm{d}$ (range $0.54-3.19 \mathrm{mg} / \mathrm{d}$ ) that is slightly higher than the mean basal requirements (range $0.5-$ $1.35 \mathrm{mg} / \mathrm{d})$, but below the toxic level of $13 \mathrm{mg} / \mathrm{d}^{(1)}$. The $\mathrm{B}$ exposure is very similar to the data reported in the literature, ranging from $0 \cdot 89$ to $2 \cdot 12^{(6,11,12,18-21)}$ and our estimation is consistent with these reports stating that normal adult daily $\mathrm{B}$ exposures are approximately $1 \mathrm{mg}$. The $\mathrm{Ba}$ exposure is $366.6 \mu \mathrm{g} / \mathrm{d}$ (range $53.1-398.3 \mu \mathrm{g} / \mathrm{d}$ ). There is no reference value with which to compare it. The Be exposure is $12 \cdot 0 \mathrm{ng} / \mathrm{d}$ (range $4 \cdot 0-14.0 \mathrm{ng} / \mathrm{d}$ ) and also for this element there is no reference value with which to compare it, nor 
any study of Be exposure in the literature in order to compare our data. The Cd exposure is $13.6 \mu \mathrm{g} / \mathrm{d}$ (range $1.4-32.7 \mu \mathrm{g} / \mathrm{d}$ ) which is well below the PTDI of $65 \mu \mathrm{g} / \mathrm{d}(7 \mu \mathrm{g} / \mathrm{kg}$ body weight per week for an adult man of $65 \mathrm{~kg}$ body weight $)^{(1)}$. This estimated value is in the range of those reported in various European and extra European countries (10.0$50 \cdot 0 \mu \mathrm{g} / \mathrm{d})^{(7,16,22-34)}$. The Ce exposure is $154.8 \mu \mathrm{g} / \mathrm{d}$ (range $124.5-197.2 \mu \mathrm{g} / \mathrm{d}$ ). There is no reference value with which to compare it, nor any study of Ce exposure in the literature in order to compare our data. The Co exposure is $29.0 \mu \mathrm{g} / \mathrm{d}$ (range $15.0-57.0 \mu \mathrm{g} / \mathrm{d}$ ). There are no recommended dietary allowances for this element. Our value is in the range of those reported in various European and extra European countries $(4 \cdot 0-29 \cdot 0 \mu \mathrm{g} / \mathrm{d})^{(11-13,15,35)}$. The Cs exposure is $4.91 \mathrm{mg} / \mathrm{d}$ (range $0.54-7.93 \mathrm{mg} / \mathrm{d}$ ) and it falls within the range of values reported in the literature (1.46$9.0 \mathrm{mg} / \mathrm{d})^{(12,35-37)}$. There is no reference value with which to compare it. The $\mathrm{Cu}$ exposure is $1.14 \mathrm{mg} / \mathrm{d}$ (range $0.73-$ $1.96 \mathrm{mg} / \mathrm{d}$ ) and it adequately satisfies the Italian RDA ${ }^{(9)}$ $(1.2 \mathrm{mg} / \mathrm{d})$. Our estimated value is in agreement with those reported in a wide recent review obtained from twenty-four European countries $(0 \cdot 54-1.77 \mathrm{mg} / \mathrm{d})^{(38,39)}$. The Fe exposure is $11.0 \mathrm{mg} / \mathrm{d}$ (range $6.41-19.45 \mathrm{mg} / \mathrm{d}$ ) and it satisfies the Italian $\operatorname{RDA}^{(9)}$ for a male $(10 \mathrm{mg} / \mathrm{d})$, but it is below the recommended value for an adult woman $(18 \mathrm{mg} / \mathrm{d})$. It is in the range of the value reported in the literature (9.0$15.9 \mathrm{mg} / \mathrm{d})^{(6,12,13,35,39-41)}$. The $\mathrm{Ge}$ exposure is $10.7 \mu \mathrm{g} / \mathrm{d}$ (range $1.1-17.5 \mu \mathrm{g} / \mathrm{d}$ ). There is no reference value with which to compare it. Our value is slightly higher than the one reported by Ysart et al. ${ }^{(6)}$ in the UK, equal to $7.0 \mu \mathrm{g} / \mathrm{d}$. The $\mathrm{Li}$ exposure is $29.9 \mu \mathrm{g} / \mathrm{d}$ (range 8.2-42.4 $\mu \mathrm{g} / \mathrm{d}$ ). This element is known to be essential for laboratory animals, but there is no scientific evidence on its essentiality for man ${ }^{(1)}$. Our value is in the range of those of the literature $(11 \cdot 0-31.0 \mu \mathrm{g} / \mathrm{d})^{(6,12,13,15)}$. The Mn exposure is $1.38 \mathrm{mg} / \mathrm{d}$ (range $0.45-2.19 \mathrm{mg} / \mathrm{d}$ ) and it satisfies the Italian $\mathrm{RDA}^{(9)}$ $(1-10 \mathrm{mg} / \mathrm{d})$ at the lower value of recommendation. Our value is slightly lower than those reported in the literature $(2 \cdot 15-2 \cdot 72 \mathrm{mg} / \mathrm{d})^{(11,16,40,42)}$. The Mo exposure is $79.6 \mu \mathrm{g} / \mathrm{d}$ (range $32 \cdot 6-106 \cdot 2 \mu \mathrm{g} / \mathrm{d}$ ) and it clearly satisfies the Italian $\operatorname{RDA}^{(9)}(50-100 \mu \mathrm{g} / \mathrm{d})$. Nevertheless, it is below the values reported in the literature $(112-131 \mu \mathrm{g} / \mathrm{d})^{(6,12,13,15,16)}$. The $\mathrm{Ni}$ exposure is $361.1 \mu \mathrm{g} / \mathrm{d}$ (range $45 \cdot 0-764.2 \mu \mathrm{g} / \mathrm{d}$ ) and it is below the PTDI ${ }^{(1)}(600 \mu \mathrm{g} / \mathrm{d})$, even though the maximum exposure is higher than $600 \mu \mathrm{g} / \mathrm{d}$, a value that gives rise to allergic reactions in predisposed subjects. Our value is in the range of those reported in the literature (74.0$438.0 \mu \mathrm{g} / \mathrm{d})^{(6,7,12-15,33,42-44)}$. The $\mathrm{Pb}$ exposure is $55 \cdot 2 \mu \mathrm{g} / \mathrm{d}$ (range $25.8-66.6 \mu \mathrm{g} / \mathrm{d}$ ) that is below the PTDI of $232 \mu \mathrm{g} / \mathrm{d}$ for an adult man of $65 \mathrm{~kg}$ body weight $(25 \mu \mathrm{g} / \mathrm{kg}$ body weight per week) ${ }^{(1)}$ and it is in the range of those reported from various European and extra European countries (16.0$280 \cdot 0 \mu \mathrm{g} / \mathrm{d})^{(6,7,14,22-25,37,43,45-47)}$. The $\mathrm{Rb}$ exposure is $1.37 \mathrm{mg} / \mathrm{d}$ (range $0.66-2.27 \mathrm{mg} / \mathrm{d}$ ). There is no reference value with which to compare it. Our value is lower than that reported by Iyengar et al. ${ }^{(12)}$ in the USA, equal to $2.44 \mathrm{mg} /$ d. The Sn exposure is $1.57 \mathrm{mg} / \mathrm{d}$ (range $0.01-4.44 \mathrm{mg} / \mathrm{d}$ ) that is well below the Provisional Tolerable Weekly Intake of $14 \mathrm{mg} /$ week $(2 \mathrm{mg} / \mathrm{kg}$ body weight per $\mathrm{d}$ for an adult man of $65 \mathrm{~kg}$ body weight) ${ }^{(1)}$. Our value is in the range of those reported in the literature $(0 \cdot 03-3 \cdot 2 \mathrm{mg} / \mathrm{d})^{(6,7,12,13,16,42)}$. 
Table 3. Mean, minimum and maximum daily exposure to twenty-one trace elements in the Northern Italian adult population*

\begin{tabular}{|c|c|c|c|c|c|c|c|}
\hline $\begin{array}{l}\text { Trace } \\
\text { elements }\end{array}$ & Mean value & Minimum value & Maximum value & PTDI† & Italian RDA & $\begin{array}{l}\% \text { of PTDI or } \\
\text { Italian RDA }\end{array}$ & $\begin{array}{l}\text { TDS data from the } \\
\text { literature (range) }\end{array}$ \\
\hline $\mathrm{Al}(\mathrm{mg})$ & 3.58 & 0.28 & $5 \cdot 15$ & 65 & & 6 & $1 \cdot 9-12 \cdot 0^{(6,7,11-17)}$ \\
\hline $\mathrm{B}(\mathrm{mg})$ & 1.65 & 0.54 & 3.19 & 13 & & 13 & $0 \cdot 89-2 \cdot 12^{(6,11,12,18-21)}$ \\
\hline $\mathrm{Ba}(\mu \mathrm{g})$ & $366 \cdot 6$ & $53 \cdot 1$ & $398 \cdot 3$ & - & & - & $530.0^{(6)} \S$ \\
\hline $\mathrm{Be}(\mathrm{ng})$ & $12 \cdot 0$ & 4.0 & $14 \cdot 0$ & - & & - & - \\
\hline $\mathrm{Cd}(\mu \mathrm{g})$ & $13 \cdot 6$ & 1.4 & $32 \cdot 7$ & 65 & & 21 & $10 \cdot 0-50 \cdot 0^{(7,16,22-34)}$ \\
\hline $\mathrm{Ce}(\mu \mathrm{g})$ & $154 \cdot 8$ & 124.5 & $197 \cdot 2$ & - & & - & - \\
\hline Co $(\mu \mathrm{g})$ & 29.0 & $15 \cdot 0$ & $57 \cdot 0$ & - & & - & $4 \cdot 0-29 \cdot 0^{(11-13,15,35)}$ \\
\hline Cs (mg) & 4.91 & 0.54 & 7.93 & - & & - & $1 \cdot 46-9 \cdot 0^{(12,35-37)}$ \\
\hline $\mathrm{Cu}(\mathrm{mg})$ & 1.14 & 0.73 & 1.96 & & $1 \cdot 2$ & 95 & $0.54-1 \cdot 77^{(38,39)}$ \\
\hline $\mathrm{Fe}(\mathrm{mg})$ & $11 \cdot 0$ & $6 \cdot 41$ & $19 \cdot 45$ & & $10 / 18$ & $110 / 61$ & $9 \cdot 0-15 \cdot 9^{(6,12,13,35,39-41)}$ \\
\hline $\mathrm{Ge}(\mu \mathrm{g})$ & $10 \cdot 7$ & $1 \cdot 1$ & 17.5 & - & & - & $7 \cdot 0^{(6)} \S$ \\
\hline $\mathrm{Li}(\mu \mathrm{g})$ & $29 \cdot 9$ & 8.2 & $42 \cdot 4$ & - & & - & $1 \cdot 0-31 \cdot 0^{(6,12,13,15)}$ \\
\hline $\mathrm{Mn}(\mathrm{mg})$ & 1.38 & 0.45 & $2 \cdot 19$ & & $1-10$ & $138 / 14$ & $2 \cdot 15-2 \cdot 72^{(11-16,40,42)}$ \\
\hline Mo $(\mu \mathrm{g})$ & 79.6 & $32 \cdot 6$ & $106 \cdot 2$ & & $50-100$ & $159 / 79$ & $112-131^{(6,12,13,15,16)}$ \\
\hline $\mathrm{Ni}(\mu \mathrm{g})$ & $361 \cdot 1$ & $45 \cdot 0$ & $764 \cdot 2$ & 600 & & 60 & $74 \cdot 0-438 \cdot 0^{(6,7,12-15,33,42-44)}$ \\
\hline $\mathrm{Pb}(\mu \mathrm{g})$ & $55 \cdot 2$ & $25 \cdot 8$ & $66 \cdot 6$ & 232 & & 24 & $16 \cdot 0-280 \cdot 0^{(6,7,14,22-25,37,43,45-47)}$ \\
\hline $\mathrm{Rb}(\mathrm{mg})$ & 1.37 & 0.66 & $2 \cdot 27$ & - & & - & $2 \cdot 44^{(12)} \S$ \\
\hline $\mathrm{Sn}(\mathrm{mg})$ & 1.57 & 0.01 & 4.44 & 140 & & 1 & $0 \cdot 03-3 \cdot 2^{(6,7,12,13,16,42)}$ \\
\hline $\operatorname{Sr}(\mathrm{mg})$ & $1 \cdot 14$ & 0.67 & 1.88 & - & & - & $1.40-1 \cdot 65^{(6,12,35,37)}$ \\
\hline$V(\mu \mathrm{g})$ & $12 \cdot 2$ & 3.3 & $17 \cdot 9$ & - & & - & $16 \cdot 0-28 \cdot 9^{(12,42)}$ \\
\hline $\mathrm{Zn}(\mathrm{mg})$ & $12 \cdot 0$ & 7.5 & $19 \cdot 8$ & & $10 / 7$ & $120 / 172$ & $4 \cdot 8-16 \cdot 0^{(6,7,11-16,35,39-41,48)}$ \\
\hline
\end{tabular}

PTDI, Provisional Tolerable Daily Intake; TDS, Total Diet Study.

* For details of procedures, see the Materials and methods.

†From $\mathrm{WHO}^{(1)}$.

$\ddagger$ From Società Italiana di Nutrizione Umana ${ }^{(9)}$. Where two values are given they are for males/females.

$\S$ Only one study.

The Sr exposure is $1.14 \mathrm{mg} / \mathrm{d}$ (range $0.67-1.88 \mathrm{mg} / \mathrm{d}$ ), falling within the range of the values reported in the literature $(1.40-1.65 \mathrm{mg} / \mathrm{d})^{(6,12,35,37)}$. There is no reference value with which to compare it. The $\mathrm{V}$ exposure is $12.2 \mu \mathrm{g} / \mathrm{d}$ (range $3.3-17.9 \mu \mathrm{g} / \mathrm{d}$ ) and it is lower than the values in the literature $(16 \cdot 0-28.9 \mu \mathrm{g} / \mathrm{d})^{(12,42)}$. There is no reference value with which to compare it. The $\mathrm{Zn}$ exposure is $12.0 \mathrm{mg} / \mathrm{d}$ (range $7.5-$ $19.8 \mathrm{mg} / \mathrm{d}$ ) and it clearly satisfies the Italian $\mathrm{RDA}^{(9)}$ both for males $(10 \mathrm{mg} / \mathrm{d})$ and females $(7 \mathrm{mg} / \mathrm{d})$. Our value is within the range of the estimated values reported in the literature $(4 \cdot 8-16 \cdot 0 \mathrm{mg} / \mathrm{d})^{(6,7,11-16,35,39-41,48)}$.

\section{Discussion}

A TDS is a tool aimed at achieving the most accurate exposure estimates of a population's diet, either as exposure levels of nutrients or toxic compounds, and which can then offer important information about the nutritional quality of the diet as well as about potential nutritional problems. Therefore, it is used in many countries to evaluate food safety risks and offers several advantages to managers involved in food safety for guiding and orienting suitable programmes. First, it has the advantage of providing more realistic exposure data since foods are analysed 'as consumed' by the eater. Secondly, it provides a good tool for identifying the population or age groups most exposed (children, elderly, etc.) and can identify the main foods or food groups that contribute most greatly to the exposure. Finally, it provides data usable for international comparison among TDS.

Nevertheless, many factors may be considered when estimating the exposure of any dietary component, including the concentration of the component in foods, the amount of food consumed, the frequency of consumption and the proportion of population that consumes the food.
Estimated exposure of compounds from the TDS are based on average per-capita food consumption; that is, the diet reflects the average amounts consumed by the entire population (consumer and non-consumer alike). While the TDS provides a rich source of information on the major dietary sources and average dietary exposure of nutrients as well as of toxic compounds, it is not designed for estimating exposure at the extremes (upper or lower percentiles) or those population subgroups that may have specific nutritional needs (e.g. pregnant and lactating women).

The present study focuses on twenty-one trace elements in a TDS conducted in a Northern area of Italy and provides information on their daily average exposure by the adult population, increasing the contribution to the scientific literature in this field.

The 'market basket' method was slightly modified. We collected most samples of foods, just ready to eat, in a cafeteria, instead of purchasing them in local markets and then preparing and cooking the foods following the Italian traditional recipes. We chose to follow this method since the funding obtained for this research was sufficient only for carrying out the analytical analyses. Indeed, we are confident that the foods prepared in the cafeteria are not different from those purchased in the markets.

In Italy, a few studies were carried out recently on trace element exposure ${ }^{(33,39)}$, but they did not investigate so many trace elements. Other studies have been conducted previously $^{(34,44,47,49-51)}$, especially on heavy metal exposure.

Mean exposure values satisfy the Italian $\mathrm{RDA}^{(9)}$ for all the essential trace elements, except for Fe exposure in females, and they are well below the PTDI ${ }^{(1)}$ for all the toxic compounds. As far as Fe exposure is concerned, a potential risk of anaemia in the female adult population should be 
considered, since its total daily exposure is derived mostly from plant foods, so most $\mathrm{Fe}$ exposure is non-haem Fe. In some previous studies conducted on trace elements and iron exposure in European and extra European countries ${ }^{(52-59)}$, Fe exposure was the major health concern, since it appeared to be inadequate in several countries in groups of the population. It would be considered that in this TDS most $\mathrm{Fe}$ exposure is derived from plant foods, and then it is nonhaem Fe. Therefore, studies aimed at evaluating the Fe nutritional status of adult Italian women should be addressed.

The high exposure of Ni, but below the PTDI ${ }^{(1)}$, is in agreement with the data found previously in a study conducted in the same area as ours by Roggi et al. ${ }^{(44)}$ and may be explained by its release from steel cookeries.

Concerning those trace elements for which no RDA or PTDI were provided, we cannot give any evaluation on their exposure, but only report their values of exposure. In addition, we cannot compare $\mathrm{Be}$ and $\mathrm{Ce}$ exposure with other data, since there are no TDS data about these trace elements in the literature.

Furthermore, the present findings may identify the specific food groups that contribute to a major or minor extent to the dietary exposure of these elements. As shown by Turrini et al. ${ }^{(10)}$ in their Italian Household National Survey, the Italian diet is a plant-centred diet, with cereal, fruit and vegetable food groups having the highest daily consumption. Indeed, cereal, fruit and vegetable food groups contribute highly to most of the trace element exposure. Also protein-rich foods are good contributors, while milk and dairy products generally give a small contribution, except in the case of $\mathrm{Al}, \mathrm{Ba}, \mathrm{Ce}, \mathrm{Ni}$ and $\mathrm{Zn}$; finally, sweet foods and beverages are negligible contributors.

The present study has some limitations that must be considered. The food samples were only collected in a selected area in Northern Italy and so the results cannot be transferred to the entire Italian population. Furthermore, the samples were collected only once, during summer, and so the data are representative of the element exposure only for a selected period of the year. As far as the sample collection goes, we have in mind to repeat the food collection and analyses during another season of the year, such as in winter, in order to study seasonal variation. Finally, the present study was confined only to the adult fraction of the population. Thus, while not excluding the possibility that the daily exposure determined in the present study may not be representative of the population as a whole, the present study provides a good estimate of the Italian adult consumer exposure to twenty-one trace elements. It would be of interest also to evaluate the exposure for maximum food consumption data, especially for consumers with specific diet behaviour, such as vegetarians and vegans, who may be at a higher risk of exceeding the PTDI/Provisional Tolerable Weekly Intake of heavy metals.

\section{Conclusions}

The present study reveals that, for an adult population living in a northern area of Italy, the observed levels of the essential and probably essential trace elements estimated with the 'market basket' TDS are on the whole satisfactory compared with the Italian RDA, where recommendations are provided. The only critical trace element exposure is that of 
Fe, regarding which suggestions were addressed. Concerning potentially toxic elements, the study shows that, for the population investigated, the probability of dietary exposure to health risks from such elements is overall small.

\section{Acknowledgements}

The authors state that there are no financial or other contractual agreements that might cause conflicts of interest. The research obtained funding from the Italian Ministry of Health. Each author has participated actively in the work and has given substantial contribution: G. T., project of the study, data analysis and supervisor; C. M., analytical analyses and supervisor; A. R., analytical analyses; C. R., supervisor. The Italian Ministry of Health is thanked for funding the research.

\section{References}

1. World Health Organization (1996) Trace Elements in Human Nutrition and Health. Geneva: WHO.

2. Abrahams PW (2002) Soils: their implications to human health. Sci Total Environ 291, 1-32.

3. Pennington JAT \& Gunderson EL (1987) History of the Food and Drug Administration's Total Diet Study - 1961 to 1987. J AOAC Int 70, 772-782.

4. Tsuda T, Inoue $T$, Kojima M \& Aoki S (1995) Market basket and duplicate portion estimation of dietary exposure of cadmium, mercury, arsenic, copper, manganese, and zinc by Japanese adults. J AOAC Int 78, 1363-1368.

5. Pennington JAT, Capar SG, Parfitt CH \& Edwards CW (1996) History of the Food and Drug Administration's Total Diet Study (Part II), 1987-1993. J AOAC Int 79, 163-170.

6. Ysart G, Miller P, Crews H, Robb P, Baxter M, De L'Argy C, Lofthouse S, Sargent C \& Harrison N (1999) Dietary exposure estimates of 30 elements from the UK Total Diet Study. Food Addit Contam 16, 391-403.

7. Ysart G, Miller P, Croasdale M, Crews H, Robb P, Baxter M, de L'Argy C \& Harrison N (2000) 1997 UK Total Diet Study - dietary exposures to aluminium, arsenic, cadmium, chromium, copper, lead, mercury, nickel, selenium, tin and zinc. Food Addit Contam 17, 775-786.

8. World Health Organization (2004) IWTDS, International Total Diet Workshop; 1st IWTDS, Kansas City, 1999; 2nd IWTDS, Brisbane, 2002; 3rd IWTDS, Paris, 2004. Geneva: WHO.

9. Società Italiana di Nutrizione Umana (SINU) (1996) Livelli di Assunzione Raccomandati di Energia e Nutrienti per la popolazione Italiana, LARN, revisione 1996. Rome: SINU.

10. Turrini A, Saba A, Perrone D, Cialfa E \& D'Amicis A (2001) Food consumption patterns in Italy: the INN-CA Study 1994-1996. Eur J Clin Nutr 55, 571-588.

11. Biego GH, Joyeux M, Hartemann P, Debry G, et al. (1998) Daily intake of essential minerals and metallic micropollutants from foods in France. Sci Total Environ 217, 27-36.

12. Iyengar GV, Wolf WR, Tanner JT \& Morris ER (2000) Content of minor and trace elements and organic nutrients in representative mixed total diet composites from the USA. Sci Total Environ 256, 215-226.

13. Noel L, Leblanc JC \& Guerin T (2003) Determination of several elements in duplicate meals from catering establishments using closed vessel microwave digestion with inductively coupled plasma mass spectrometry detection: estimation of daily dietary intake. Food Addit Cont 20, 44-56.

14. Santos EE, Lauria DC \& Porto da Silveira CL (2004) Assessment of daily intake of trace elements due to consumption of foodstuffs by adult inhabitants of Rio de Janeiro city. Sci Total Environ 327, 69-79.

15. Leblanc JC, Guérin T, Noël L, Calamassi-Tran G, Volatier JL \& Verger P (2005) Dietary exposure estimates of 18 elements from the 1st French Total Diet Study. Food Addit Contam 22, 624-641.

16. Aung NN, Yoshinaga J \& Takahashi JI (2006) Dietary intake of toxic and essential trace elements by the children and parents living in Tokyo Metropolitan Area, Japan. Food Addit Contam 23, 883-894.

17. Pennington JAT (1988) Aluminium content of foods and diets. Food Addit Cont 5, 119-128.

18. Meacham SL \& Hunt CD (1998) Dietary boron intake of selected populations in the United States. Biol Trace Elem Res 66, 65-78.

19. Rainey C \& Nyquist L (1998) Multicountry estimation of dietary boron intake. Biol Trace Elem Res 66, 79-86.

20. Rainey CJ, Nyquist LA, Christensen RE, Strong PL, Culver BD \& Coughlin JR (1999) Daily boron intake from the American diet (Review). J Am Diet Assoc 99, 335-340.

21. Hunt CD \& Meacham SL (2001) Aluminium, boron, calcium, copper, iron, magnesium, manganese, molybdenum, phosphorus, potassium, sodium, and zinc: concentrations in common western foods and estimated daily intakes by infants, toddlers, and male and female adolescents, adults, and seniors in the United States. $J$ Am Diet Assoc 101, 1058-1060.

22. Leblanc JC, Malmauret L, Guerin T, Bordet F, Boursier B \& Vergert $\mathrm{P}$ (2000) Estimation of the dietary intake of pesticide residues, lead, cadmium, arsenic and radionuclides in France. Food Addit Contam 17, 925-932.

23. Nasreddine L \& Parent-Massin D (2002) Food contamination by metals and pesticides in the European Union. Should we worry? Toxicol Lett 127, 29-41.

24. Llobet JM, Falco G, Casas C, Teixido A \& Domingo JL (2003) Concentrations of arsenic, cadmium, mercury, and lead in common foods and estimated daily intake by children, adolescents, adults, and seniors of Catalonia, Spain. J Agric Food Chem 51, 838-842.

25. Marzec Z \& Schlegel-Zawadzka M (2004) Exposure to cadmium, lead and mercury in the adult population from Eastern Poland, 1990-2002. Food Addit Contam 21, 963-970.

26. Urieta I, Jalon M, Eguilero I, et al. (1996) Food surveillance in the Basque Country (Spain) II. Estimation of the dietary intake of organochlorine pesticides, heavy metals, arsenic, aflatoxin M1, iron and zinc through the Total Diet Study, 1990/91. Food Addit Contam 13, 29-52.

27. Tsoumbaris P \& Tsoukali-Papadopoulou H (1994) Heavy metals in common foodstuff: daily intake. Bull Environ Contam Toxicol 53, 67-70.

28. Gunderson EL (1995) FDA Total Diet Study, July 1986-April 1991, dietary intakes of pesticides, selected elements, and other chemicals. J AOAC Int 78, 1353-1363.

29. Moon CS, Zhang ZW, Shimbo S, Watanabe T, Moon DH, Lee CU, Lee BK, Ahn KD, Lee SH \& Ikeda M (1995) Dietary intake of cadmium and lead among the general population in Korea. Environ Res 71, 46-54.

30. Saleh ZA, Brunn H, Paetzold R \& Hussein R (1998) Nutrients and chemical residues in an Egyptian total mixed diet. Food Chem 63, 535-541.

31. Ryan PB, Scanlon KA \& MacIntosh DL (2001) Analysis of dietary intake of selected metals in the NHEXAS-Maryland investigation. Environ Health Perspect 109, 121-128.

32. Muñoz O, Bastias JM, Araya M, Morales A, Orellana C, Rebolledo R \& Velez D (2005) Estimation of the dietary intake of cadmium, lead, mercury, and arsenic by the population of Santiago (Chile) using a Total Diet Study. Food Chem Toxicol 43, $1647-1655$. 
33. Alberti-Fidanza A, Burini G, Perriello G \& Fidanza F (2003) Trace element intake and status of Italian subjects living in the Gubbio area. Environ Res 91, 71-77.

34. Roggi C, Maccarini L, Mancini MC \& Ronchi A (1998) Dietary exposure to cadmium and mercury. Ann Ig 10, 95-101.

35. Jaiswal DD, Dang HS, Nair S \& Sharma RC (2002) Validating the analytical methodologies for determining some important trace elements in food consumed in India. Food Nutr Bull 23, Suppl. 3, 185-190.

36. Akhter P, Orfi SD \& Ahmad N (2003) Caesium concentration in the Pakistani diet. J Environ Radioact 67, 109-118.

37. Iyengar GV, Kawamura H, Dang HS, et al. (2004) Dietary intakes of seven elements of importance in radiological protection by Asian population: comparison with ICRP data. Health Phys 86, 557-564.

38. Sadhra SS, Wheatley AD \& Cross HJ (2007) Dietary exposure to copper in the European Union and its assessment for EU regulatory risk assessment. Sci Total Environ 374, 223-234.

39. Lombardi-Boccia G, Aguzzi A, Cappelloni M, Di Lullo G \& Lucarini M (2003) Total-diet study: dietary intakes of macro elements and trace elements in Italy. Br J Nutr 90, 1117-1121.

40. Egan SK, Tao SS, Pennington JA \& Bolger PM (2002) US Food and Drug Administration's Total Diet Study: intake of nutritional and toxic elements, 1991-96. Food Addit Contam 19, 103-125.

41. Hannon EM, Kiely M, Harrington KE, Robson PJ, Strain JJ \& Flynn A (2001) The North/South Ireland Food Consumption Survey: mineral intakes in 18-64-year-old adults. Public Health Nutr 4, 1081-1088.

42. Bocio A, Nadal M, Domingo JL, et al. (2005) Human exposure to metals through the diet in Tarragona, Spain: temporal trend. Biol Trace Elem Res 104, 193-201.

43. Larsen EH, Andersen NL, Moller A, Petersen A, Mortensen GK \& Petersen J (2002) Monitoring the content and intake of trace elements from food in Denmark. Food Addit Contam 19, 33-46.

44. Roggi C, Merlo E \& Minoia C (1997) Nickel food exposure. Ann Ig 9, 221-227.

45. Nasreddine L, Hwalla N, El Samad O, LeBlanc JC, Hamze M, Sibiril Y \& Parent-Massin D (2006) Dietary exposure to lead, cadmium, mercury and radionuclides of an adult urban population in Lebanon: a total diet study approach. Food Addit Contam 23, 579-590.

46. Kumpulainen J (1995) Proceeding of Technical Workshop on Trace Elements, Natural Antioxidants and Contaminants, vol. 49. Helsinki, Finland, 25-26 August. Rome: FAO.

47. Roggi C, Merlo E \& Minoia C (1997) Dietary lead exposure. Ann Ig 9, 59-65.
48. Terres C, Navarro M, Martin-Lagos F, Gimenez R, Lopez H \& Lopez MC (2001) Zinc levels in foods from south-eastern Spain: relationship to daily dietary intake. Food Addit Contam 18, 687-695.

49. Santaroni GP, Ingrao G, Belloni P \& Gambelli L (1992) Livelli di alcuni elementi in traccia in diete italiane. In Agrobiotecnologie nei processi di valorizzazione dei prodotti e sottoprodotti agricol, pp. 1087-1088 [RAISA, editor]. Volterra, Italy: CNR.

50. Gambelli L, Belloni P, Ingrao G \& Santaroni GP (1994) Livelli di alcuni metalli pesanti in diete di riferimento italiane. In Agrobiotecnologie nei processi di valorizzazione dei prodotti e sottoprodotti agricoli, pp. 187-192 [RAISA, editor]. Sartiano, Italy: CNR.

51. Ciappellano S, Roggi C, Baggio C, Lanza MP, Erba D, Maccarini L, Brighenti F \& Testolin G (1998) Study design of a total reference diet for a population in Northern Italy. Ann Nutr Metab 42, 127-137.

52. Lowik MRH, Brussaard JH, Hulshof KFAM, Kistemaker C, Schaafsma G, Ockhuizen TH \& Hermus RJJ (1994) Adequacy of the diet in the Netherlands in 1987-1988 (Dutch Nutrition Surveillance System). Int J Food Sci Nutr 45, Suppl. 1, S1-S62.

53. van Dokkum W (1998) Trace element intake in Europe: safe and adequate? (Review). Bibl Nutr Diet 54, 8-17.

54. Pynaert I, Delanghe J, Temmerman M \& De Henauw S (2007) Iron intake in relation to diet and iron status of young adult women. Ann Nutr Metab 51, 172-181.

55. Satalic Z, Baric IC \& Keser I (2007) Diet quality in Croatian university students: energy, macronutrient and micronutrient intakes according to gender. Int J Food Sci Nutr 58, 398-410.

56. Pennington JA (1996) Intakes of minerals from diets and foods: is there a need for concern? J Nutr 126, Suppl. 9, S2304-S2308.

57. Maitland TE (2007) Anemia in the Turks and Caicos Islands: exploring the dietary link. Ethn Dis 17, 313-319.

58. Eckhardt CL, Torheim LE, Monterrubio E, Barquera S \& Ruel MT (2007) The overlap of overweight and anaemia among women in three countries undergoing the nutrition transition. Eur J Clin Nutr 62, 238-246.

59. Thomson BM, Vannoort RW \& Haslemore RM (2007) Dietary exposure and trends of exposure to nutrient elements iodine, iron, selenium and sodium from the 2003-4 New Zealand Total Diet Survey. Br J Nutr 10, 1-12.

60. Gladney ES, Burns CE, Perrin DR, Roelandts I \& Gill TE (1984) 1982 Compilation of Elemental Concentration Data for NBS Biological, Geological, and Environmental Standard Reference Materials. NBS Special Publication no. 260-88. NBS. 